\title{
Evaluation of prebiotic and probiotic dietary supplementation on growth performance and some blood parameters of Cyprinus carpio Frys.
}

\author{
Wafaa Eleraky ${ }^{1}$; Yahya $M^{2}{ }^{2}$; Rasha M. Reda. ${ }^{3}$ and Eletreby . $^{4}$. \\ 1- Nutrition and Clinical Nutrition Department, Faculty of Veterinary Medicine, \\ Zagazig University, 44511 Zagazig, Egypt. \\ 2- Pollution Laboratory, Fish research station, El-Kanater El. Kyayria, National \\ Institute of Oceanography and Fishers, Egypt. \\ 3- Department of Fish Diseases and Management, Faculty of Veterinary Medicine, \\ Zagazig University, 44511 Zagazig, Egypt. \\ 4- Department of Marine Science, Faculty of Science, Suez Canal University, Egypt.
}

\section{ABSTRACT}

The objective of this study was to evaluate the effect of prebiotics and probiotics on the growth performance, non-specific immunity and chemical composition of Cyprinus carpio. A total of 250 fry of Cyprinus carpio with an average body weight and length were used in experiments $2.82 \pm 0.12 \mathrm{~g}$ and $3.12 \pm 0.13 \mathrm{~cm}$ were divided into five experimental groups fed the pelleted diets for 12 week as follows: groups 1 (control group) fed diet (T1), groups 2, 3 fed on diets (T2, T3) which supplemented with 1.5 and $2.5 \mathrm{~g} \mathrm{~kg}^{-1}$ Organoferum dry prebiotic respectively. Groups 4, 5 fed on diets (T4, T5) which supplemented with 0.5 and $1 \mathrm{~g} \mathrm{~kg}^{-1}$ Biogreen E probiotic respectively. The results of this study revealed that fish in group 3 had significantly higher final body weight, weight gains and specific growth rate followed by fish in group 5. Length increments and survival rate in fish of group 3 and 5 were significantly higher $(\mathrm{P}<0.05)$ than other groups. The highest crude protein and lipid content $(\mathrm{P}<0.05)$ were found in the fish fed on diets $\mathrm{T} 3$ and $\mathrm{T} 5$. Total serum protein, albumin and globulin were significantly increased in fish fed the experimental diets T5 than other groups. While, lysozyme activity were significantly increased in fish fed on the experimental diet T3. The conclusion of present study reveals that a dietary supplementation $2.5 \mathrm{~g} / \mathrm{kg}$ prebiotics was improved growth performance, and nonspecific immunity of Cyprinus carpio Frys.

Keywords: Cyprinus carpio, prebiotics, probiotics, growth, body composition.

\section{INTRODUCTION}

Chemical additives, such as anabolic steroids, growth promoters and some antibiotics are commonly administered in feed to improve growth performance and to control the outbreak of diseases in aquaculture (Gaunt et al. 2010 and Defoirdt et al. 2011). In recent years, the research on pro- and prebiotics in fish nutrition is increasing with the demand for the consumer and environment-friendly aquaculture (Denev 2009).

A prebiotic is defined as a non-digestible dietary ingredient that beneficially affects the host by selectively stimulating the growth of and/or activating the metabolism of health-promoting bacteria in the gastrointestinal tract (Manning and Gibson 2004). Results from several studies have indicated that prebiotics can improve growth performance and feed utilization of various fish species (Burr et al. 2008; Grisdale-Helland et al. 2008; Yousefian and Amiri 2009), enhance their non-specific 
immune responses and resistance to bacterial infections (Li and Gatlin 2005; Staykov et al. 2007; Buentello et al. 2010).

Probiotic is any live microbial supplement, which beneficially affects the host animal by improving its microbial balance (Gram et al. 1999). Since the first use of probiotics in aquaculture, growing number of studies have demonstrated their ability to increase the growth rate and welfare of farmed aquatic animals (Wang et al. 2005; Wang and $\mathrm{Xu}$ 2006; Wang 2007). The probiotics in aquaculture have been shown to have several modes of action: competitive exclusion of pathogenic bacteria through the production of inhibitory compounds; improvement of water quality; enhancement of immune response to host species; and enhancement of nutrition of host species through the production of supplementary digestive enzymes (Thompson et al. 1999; Carnevali et al. 2006).

Present study was planned to investigate the effect of probiotic and prebiotic on growth performance, body composition and nonspecific immune response of Cyprinus carpio fry.

\section{MATERIALS AND METHODS}

\section{Measurements of water quality parameters:-}

Chemical analysis of water temperature, $\mathrm{pH}$, Dissolved oxygen and Ammonia were carried out by different methods according to Boyd (1984) and APHA (1985).

\section{Diets and feed additives}

\section{Basal diet:}

The control basal diet (T1) was without any additives and contained approximately $35 \%$ crude protein and $5.9 \%$ crude lipid (Table 1 ).

Table 1: Composition of basal diet.

\begin{tabular}{lclc} 
Ingredients & Content (\%) & \multicolumn{2}{c}{ Chemical analysis\% } \\
Soya48 & 49.5 & Dry matter \% & 91.7 \\
Rice bran & 24.5 & Crude protein\% & 35.0 \\
Corn & 15.2 & Ether extract \% & 8.9 \\
Wheat middling & 4.00 & Ash\% & 5.8 \\
Soya oil & 1.8 & Fiber $\%$ & 6.0 \\
Gelatin & 1.5 & ${ }^{3}$ GE $(\text { Kcal } / 100 \mathrm{~g})^{4}$ & 389.32 \\
Salt & 0.5 & & \\
${ }^{1}$ Minerals premix & 1.5 & & \\
${ }^{2}$ Vitamins premix & 1.5 & & \\
total & 100 & &
\end{tabular}

1-Minerals mix.: Each $\mathrm{kg}$ contain manganese $60 \mathrm{~g}$, iron $80 \mathrm{~g}$, copper 5g, zinc 40g, selenium 0.15 and iodine $0.35 \mathrm{~g}$.

2- Vitamins mix. Provide (g, mg or 1.U kg diet) Vit. A 5000 I. U ,D32.000 I.U, E 100mg, k3 10.0mg, C. $1.000 \mathrm{mg}$. B1 10mg, B2 15.0mg, B6 7.5mg, B12 0.1mg, Biotin 0.2mg, Folicacid 0.4mg, cholin Hcl $1.0 \mathrm{~g}$ inosit. $3000.0 \mathrm{mg}$, patathemic acid $50.0 \mathrm{mg}$, Nicotinic acid $100 \mathrm{mg}$, P-Aminobenzonic acid $50.0 \mathrm{mg}$.

3- Gross energy: Based on $5.65 \mathrm{Kcal} / \mathrm{g}$ proteins, $9.45 \mathrm{Kcal} / \mathrm{g}$ fat and 4.1 carbohydrate $\mathrm{Kcal} / \mathrm{g}(\mathrm{NRC}$, 1993).

\section{Feed additives:}

- Organoferm Dry ${ }^{\circledR}$ (A.T.C.O. Pharma Company -Tanta city) each $1 \mathrm{~kg}$ contained 9.2\% MOS and 11.7\% 1:3, 1:6 Beta-glucans.

- Biogreen E (Samu median Co-LTD) each 1 kg contain: 


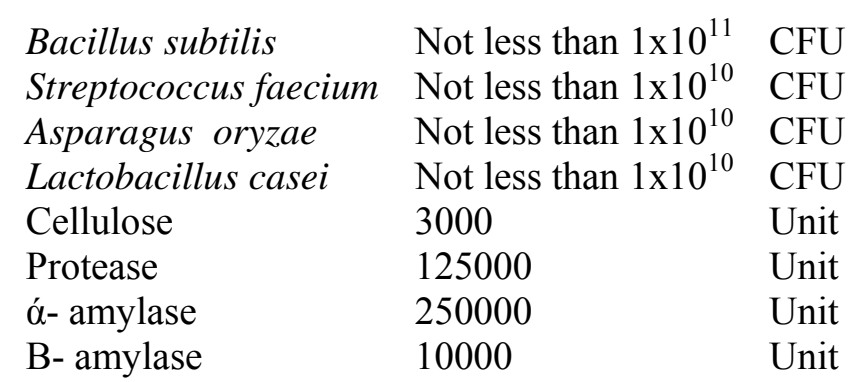

The four experimental diets that manufactured consist of as follows: T2, T3 which supplemented with 1.5 and $2.5 \mathrm{~g} \mathrm{~kg}^{-1}$ Organoferum dry prebiotic respectively. $\mathrm{T} 4$, T5 which supplemented with 0.5 and $1 \mathrm{~g} \mathrm{~kg}^{-1}$ Biogreen E probiotic respectively.

\section{Fish \& Experimental design}

A total number of 250 apparently healthy Cyprinus carpio collected from ElAbbassa Fish Hatchery-The General Authority for Fish Resources Development ElAbbassa Sharkia Governorate. The average body weight $2.82 \pm 0.124 \mathrm{~g}$ and $3.12 \pm$ $0.13 \mathrm{~cm}$ of length were used in experiment. Fish were located in glass aquaria $(40 \times 30 \times 250 \mathrm{~cm})$ and filled with dechlorinated tap water provided with aerating devices and Thermostatic heaters. The fish were adapted to experimental condition for two weeks before the start of the experiment. Fish were divided into five equal groups, each with two replicate ( 25 fish replicate ${ }^{-1}$ ) fed the pelleted diets as follows: groups 1 (G1) (control group) fed basal diet (T1), groups 2, $3(\mathrm{G} 2,3)$ fed on diets T2, T3. Groups 4, $5(\mathrm{G} 4,5)$ fed on diets T4, T5. All fish groups were fed on the diets at the rate of 5\% from the body weight during 12 weeks of the experiment. The fish weight and length were taken at the start and every two weeks during the experiment.

\section{Sampling and analytical methods}

\section{Growth performance}

The fish were weighed every two weeks to assess growth performance. The final body weight (FBW), weight gain (WG), specific growth rate (SGR), feed conversion ratio (FCR) and body length increment were determined according to Castle and Tiews (1980); Siddiqui et al. (1988) and De Silva and Anderson (1995).

\section{Body composition}

Five fish samples from each replicate were analyzed for dry matter, crud protein, ether extract and ash according to standard method (AOCA, 1990).

\section{Blood analysis}

Blood samples were collected at the end of the experimental period from the caudal vessels. Three fish per group randomly collected from each group, used for serum collection without adding anticoagulant. The blood sample was allowed to clot \&centrifuged at 3000 r.p.m for $15 \mathrm{~min}$, for obtaining nonhemolysed serum which used for determination of total protein (Henry and clim 1964), albumin (Wotton and freeman 1982). Globulin was determined by direct subtracting the values of the albumin from those of the total protein. Lysozyme activity of blood serum was determined as described by Anderson and Siwicki (1995).

\section{Statistical analysis}

The mean and standard error were calculated for each variable. The data were analyzed by analysis of variance (ANOVA) to identify the significantly different groups at $(\mathrm{P}<0.05)$ using SPSS software statistical program (SPSS for windows ver.15.00, USA). 


\section{RESULTS AND DISCUSSION}

Physicochemical parameters were measured along experimental period. Average temperature $\left({ }^{\circ} \mathrm{C}\right), \mathrm{pH}$, dissolved oxygen $(\mathrm{mg} / \mathrm{l})$ and ammonia $(\mathrm{mg} / \mathrm{l})$ were $21.4 \pm 0.6,7.2 \pm 0.12,7.8 \pm 0.12$ and $0.017 \pm 0.013$ respectively.

The growth performances and individual length increments of fish in different groups are shown in Table (2). Fish fed diet T3 was significantly higher final body weight, weight gain and specific growth rate followed by fish group fed T5. The lowest values were observed in the untreated control group. While feed conversion ratio was significantly lower in fish fed diet T3 compared to control group. Fry fed the diets T3 and T5 was significantly higher final body length $(\mathrm{P}<0.05)$ followed by fry fed the experimental diets T2 and T4 than those of the control group. The fry fed the diet T5 had significantly higher $(\mathrm{P}<0.05)$ mean individual length increments compared to the other groups. Similar results have been reported for Saccharomyces cerevisiae used in diets for carp (Noh et al. 1994), Nile tilapia Lara-Flores et al. (2003).

Table 2: Effect of dietary supplementation with prebiotic and probiotic on growth performance of Cyprinus Carpio fry.

\begin{tabular}{|l|c|c|c|c|c|}
\hline \multirow{2}{*}{ parameters } & \multicolumn{5}{c|}{ Treatments } \\
\cline { 2 - 6 } & $\mathrm{T} 1$ & $\mathrm{~T} 2$ & $\mathrm{~T} 3$ & $\mathrm{~T} 4$ & $\mathrm{~T} 5$ \\
\hline Initial body weight $(\mathrm{g})$ & $2.69 \pm 0.094^{\mathrm{a}}$ & $2.62 \pm 0.14^{\mathrm{a}}$ & $2.52 \pm 0.12^{\mathrm{a}}$ & $2.94 \pm 0.12^{\mathrm{a}}$ & $3.35 \pm 0.13^{\mathrm{a}}$ \\
\hline Final body weight $(\mathrm{g})$ & $10.34 \pm 0.20^{\mathrm{d}}$ & $12.88 \pm 0.25^{\mathrm{c}}$ & $15.53 \pm 0.36^{\mathrm{a}}$ & $12.56 \pm 0.3^{\mathrm{c}}$ & $14.64 \pm 0.3^{\mathrm{b}}$ \\
\hline Weight gain (g/fish & $7.65 \pm 0.16^{\mathrm{d}}$ & $10.26 \pm 0.13^{\mathrm{c}}$ & $12.98 \pm 0.21^{\mathrm{a}}$ & $9.56 \pm 0.19^{\mathrm{bc}}$ & $11.29 \pm 0.14^{\mathrm{b}}$ \\
\hline Specific growth rate (\%) & $1.42 \pm 0.27^{\mathrm{c}}$ & $1.64 \pm 0.20^{\mathrm{b}}$ & $1.86 \pm 0.28^{\mathrm{a}}$ & $1.45 \pm 0.34^{\mathrm{c}}$ & $1.58 \pm 0.25^{\mathrm{bc}}$ \\
\hline Feed intake (g) & $23.1 \pm 0.34^{\mathrm{d}}$ & $29.6 \pm 0.17^{\mathrm{b}}$ & $29.8 \pm 0.21^{\mathrm{b}}$ & $27.5 \pm 0.31^{\mathrm{c}}$ & $33.4 \pm 0.22^{\mathrm{a}}$ \\
\hline Feed conversion ratio & $3.0 \pm 0.13^{\mathrm{a}}$ & $2.8 \pm 0.19^{\mathrm{c}}$ & $2.3 \pm 0.13^{\mathrm{d}}$ & $2.8 \pm 0.17^{\mathrm{c}}$ & $2.9 \pm 0.26^{\mathrm{b}}$ \\
\hline Initial body length $(\mathrm{cm})$ & $3.4 \pm 0.12^{\mathrm{a}}$ & $3.9 \pm 0.14^{\mathrm{a}}$ & $3.4 \pm 0.12^{\mathrm{a}}$ & $3.8 \pm 0.11^{\mathrm{a}}$ & $4.1 \pm 0.115^{\mathrm{a}}$ \\
\hline Final body length $(\mathrm{cm})$ & $8.7 \pm 12^{\mathrm{c}}$ & $9.1 \pm 20^{\mathrm{b}}$ & $9.8 \pm 24^{\mathrm{a}}$ & $9.1 \pm 12^{\mathrm{b}}$ & $9.6 \pm 18^{\mathrm{a}}$ \\
\hline length increment $(\mathrm{cm})$ & $5.3 \pm 0.14^{\mathrm{b}}$ & $5.20 \pm 0.18^{\mathrm{b}}$ & $6.40 \pm 0.11^{\mathrm{a}}$ & $5.3 \pm 0.17^{\mathrm{b}}$ & $5.5 \pm 0.17^{\mathrm{b}}$ \\
\hline Condition factor & $1.57 \pm 0.03^{\mathrm{c}}$ & $1.71 \pm 0.03^{\mathrm{a}}$ & $1.65 \pm 0.02^{\mathrm{c}}$ & $1.66 \pm 0.08^{\mathrm{b}}$ & $1.65 \pm 0.02^{\mathrm{c}}$ \\
\hline
\end{tabular}

Rengpipat et al. (1998) and Prabhu et al. (1999) reported that the probiotic treated group enhanced growth rate of shrimps. Survival of shrimps was significantly greater in treated group compared with the control group. Olvera et al. (2001) concluded that yeast had a positive effect on fish performance when cultured under stress condition of lowering dietary protein. Gibson et al. (2004) suggested that a prebiotic has to resist gastric acidity, hydrolysis by (mammalian) enzymes, GI absorption, fermented by the intestinal micro biota and stimulate selectively the growth and/or activity of intestinal bacteria associated with health and well-being. Elharoun et al. (2006) reported that with Biogen ${ }^{\circledR}$ as feed additive containing B. subtilis came to the conclusion that, this organism germinates in the intestine of fish, using a large numbers of sugar (carbohydrates) and produces a wide range of digestive enzymes (amylase, lipase and protease) which have a beneficial effects including higher growth rate and higher feed efficiency. Yanbo and Zirong (2006) found that for common carp, Bacillus spp can produce secondary metabolites which have been used industrially for production of antibiotics, bioinsecticides, fine chemicals and enzymes that readily hydrolyze carbohydrates, lipids and proteins into sugars, fatty acids, peptides and amino acids. 
In contrast, Hidalgo et al., (2006) found that growth and feed conversion of juvenile dentex were not significantly influenced by probiotics. Shelby et al. (2006) found that the probiotic used with juvenile channel catfish diet had lack effect on specific growth promoting or immune stimulating aspects. Mazlum et al. (2011) found great growth in Astacus leptodactylus juveniles fed with MOS while the survival rate was not affected.

The survival rate was significantly higher $(\mathrm{P}<0.05)$ in fry fed diets $\mathrm{T} 3$ and T5 followed by fry fed the diets T2 and T4 than those of the control group (Fig. 1). Also, the present result agree with Kennedy et al. (1998) who find that the addition of a gram-positive probiotic bacterium increased survival, and growth rate of marine fish larvae (snook, red drum, spotted sea trout and stripped mullet). Tovar-Ramírez et al. (2004) noticed that the growth of larvae of sea bass fed $1.1 \%$ live yeast as a probiotic was increased than control group. Also, survival rate of larvae was significantly higher than the control. Bagni et al. (2005) fed two groups of sea bass (Dicentrarchuslabrax) with a Macrogard diet containing $0.1 \%$ yeast B-glucans derived from the wall of Saccaromyces cerevisiae, they found that condition factor ranged from 0.82 to 1.35 , and did not vary among the groups throughout the experiment. Kumar et al. (2006) found that an increased growth rate and survival rate which were observed in Indian major carp (Labeo Rohit) fed diet contained Bacillus subtilis compared with control. Wang and GU (2010) showed that increased the growth performance of grass carp fingerlings (Ctenopharyngodon idella) fed with diet contained of Bacillus coagulans, Rhodopseudomonas palustris and Lactobacillus acidophilus.

$\square \mathrm{G} 1 \square \mathrm{G} 2 \square \mathrm{G} 3 \mathrm{EG} 4 \mathrm{G5}$

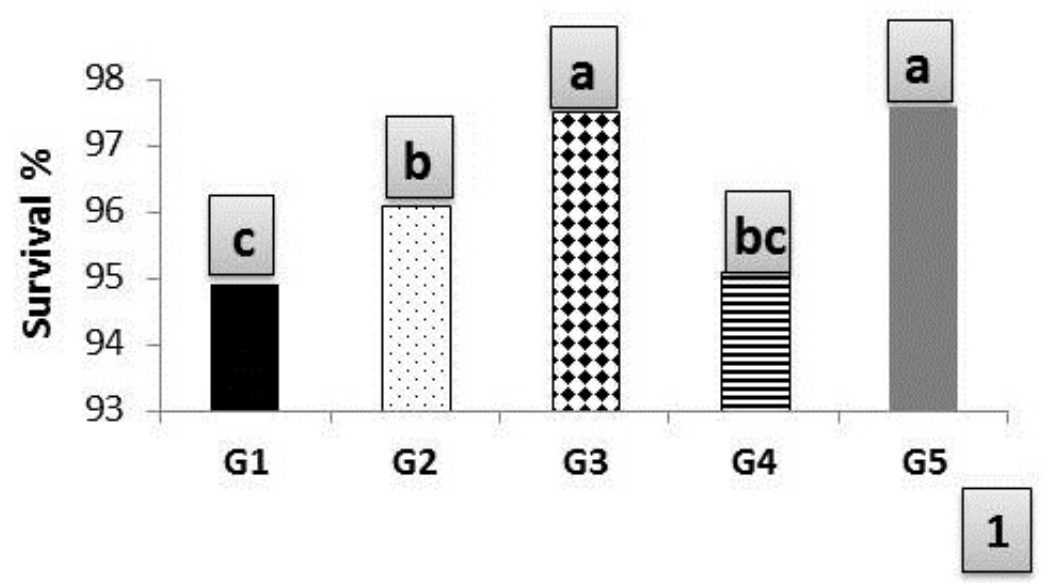

Fig. 1: Effect of dietary supplementation with prebiotic and probiotic on survival rate of Cyprinus Carpio fry.

The result of proximate analyses of whole body is present in (Fig.2). There was an increase the protein and fat content of fry fed diets T3 and T5 than other groups. These results go paralleled with the results obtained by Sealey et al. (2007) who used different levels of B-glucan on control diet for rainbow trout. Fish fed the wheat control diet or the high B-glucan barley diet had significantly higher moisture content than fish fed the low B-glucan barley diet following 3 weeks of feeding. AbdelTawwab et al. (2008) suggested that yeast supplementation played a role in enhancing feed intake with a subsequent enhancement of fish body composition. Similar results 
have been observed in other fish species such as rainbow trout (Yilmaz et al. 2007) and hybrid tilapia (Genc et al. 2007a) when use Mannan Oligosaccharides (MOS).
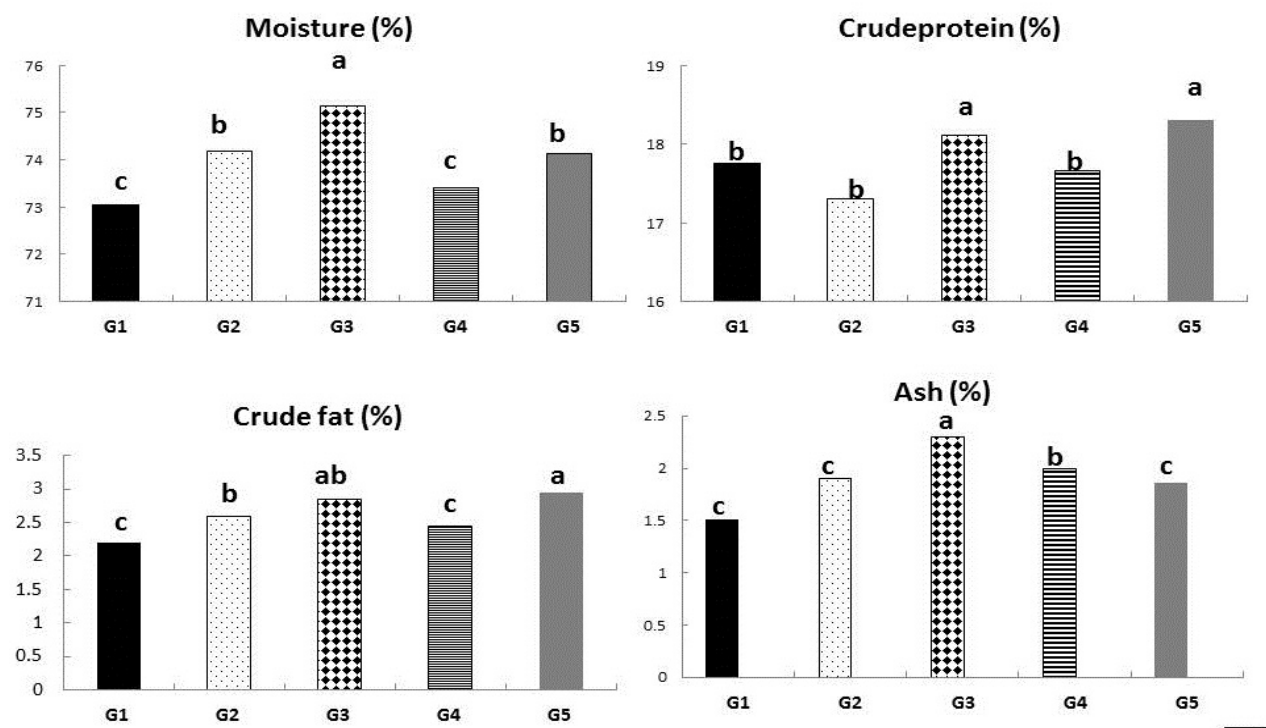

Fig. 2: Effect of dietary supplementation with prebiotic and probiotic on Body composition of Cyprinus Carpio fry.

Total serum protein, albumin and globulin were significantly increased in fish group fed the experimental diet T5 than other groups (Fig. 3). While, lysozyme activity were significantly increased in fish fed the diet T3 followed by fish fed the diet $\mathrm{T} 5$ then fish fed the diets $\mathrm{T} 2$ and T4 compared to control group.

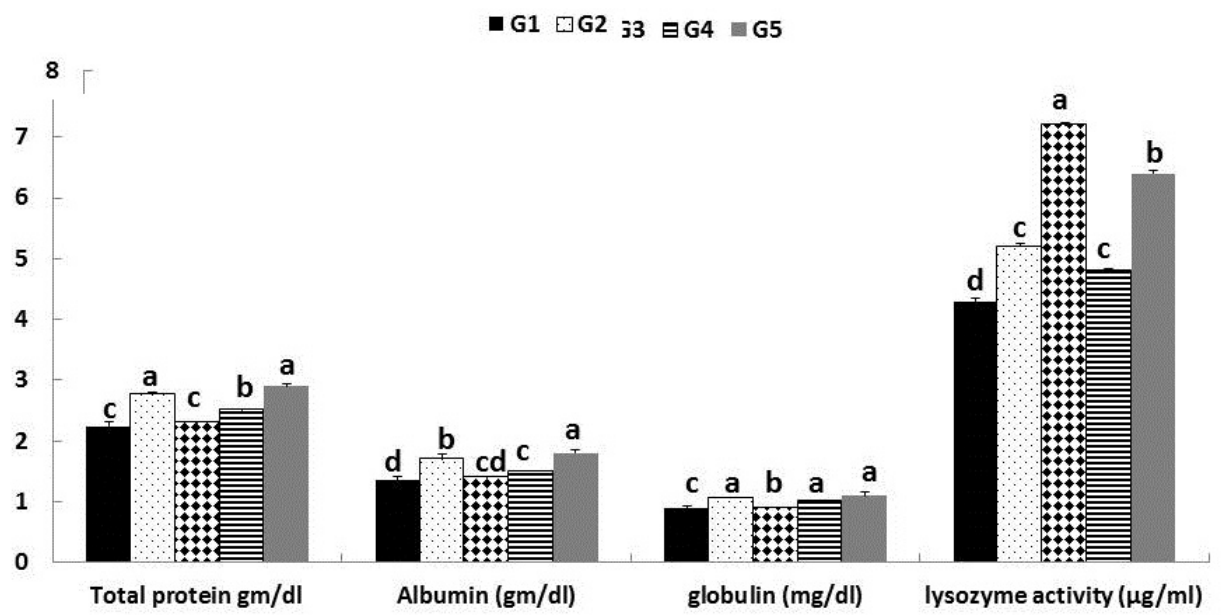

Fig. 3: Effect of dietary supplementation with prebiotic and probiotic on some immunological parameters of Cyprinus Carpio fry.

The use of probiotics improved the nutrition level of aquacultural and improves immunity to pathogenic microorganisms. Rengpipat et al. (2000) who observed that Bacillus sp. provided disease protection to shrimp by activating both cellular and 
humoral immune defenses. Nayak et al. (2007) reported that glucan of yeast improved production antibody of carp (Cyprinus carpio) infected with Aeromonas hydrophila. Tewary and Patra (2011) reported that the possible role of yeast as an imunostimulant may be attributed to its cell wall which composed of lipopolysaccharide such as glucan, which enhanced phagocytic activity of macrophages and globulin level as observed in the present experiment. Conversely, Kobeisy and Hussein (1995) studied effect of $0,5,10$ and $20 \%$ dietary live yeast on the serum total protein and globulin of Oreochromis niloticus for 13 weeks. They found that both of serum total protein and globulin concentration was lower in treated groups than in control.

\section{CONCLUSION}

Considering the findings emphasized in the previous topics of the paper the fish diet supplemented with probiotic and prebiotic enhance their growth performance and nonspecific immune response.

\section{REFERENCES}

Abdel-Tawwab M, Abdel-Rahman AM and Ismael NEM (2008). Evaluation of commercial live bakers' yeast, Saccharomyces cerevisiae as a growth and immunity promoter for fry Nile tilapia, Oreochromis niloticus (L.) challenged in situ with Aeromonas hydrophila. Aquacult., 280:185-189.

APHA (1985). American Public Health Association. Standard Methods for the examination of water and waste water $15^{\text {th }}$ edition. pp. 476 .

A.O.A.C. (1990). "Official Methods of Analysis. Association of Official Analytical Chemists." Washington, DC. J. C. Abbott, 1966. Adv. Chem. 5er. 57, 13.

Anderson DP and Siwicki AK (1995). Basic hematology and serology for fish health programs. In: Diseases in Asian Aquaculture II. (M. Shariff, J.R. Auther \& R.P. Subasinghe ed.), pp. 185-202, Fish Health Section, Asian Fish. Soci., Manila.

Bagni M, Romano N, Finoia MG, Abelli L, Scapigliati G, Tiscar PG, arti M and Marin G (2005). Short and long-term effects of a dietary190 yeast B- glucan (Macrogard) and alginic acid (Ergosan) preparationon immune response in sea bass (Dicentrarchus labrax). Fish \&Shellfish Immunology, 18: 311-325.

Boyd CE, Hollerman WD, Plumb JA and Saeed M (1984): Effect of treatment with a commercial bacterial suspension on water quality in channel catfish ponds. Progressive Fish-Culturist, 46:36-40.

Buentello JA, Neill WH and Gatlin III DM (2010). Effects of dietary prebiotics on growth, feed efficiency and non-specific immunity of juvenile red drum Sciaenops ocellatus fed soybean-based diets. Aquacult. Res., 14:411-418.

Burr G, Hume WH Neill and Gatlin III. DM (2008). Effects of prebiotics on nutrient digestibility of soybean-meal-based diets by red drum (Sciaenops ocellatus). Aquacult. Res., 39:1680-1686.

Castle JD and Tiews K (1980). Standardization of methodology in fish nutrition research. Report of EIFAC, IUNS and ICES working group on EIFAC (technical paper Nr. 36, EIFACT36.

Defoirdt T, Sorgeloos P and Bossier P (2011). Alternatives to antibiotics for the control of bacterial disease in aquaculture. Current Opinion in Microbiology. $14: 251-258$.

De Silva SS and Anderson TA (1995). Fish Nutrition in Aquaculture. Chapman \& Hall Aquaculture Series, London, pp.319 
El-Haroun, ER.; Goda, A.M. and Kabir, Chowdhury M. A. (2006). Effect of dietary probiotic biogen supplementation as a growth promoter on growth performance and feed utilization of Nile tilapia Oreochromis niloticus (L.) Aquacult. Res., 37(14): 1473-1480

Gaunt, PS.; Endris, R.; McGinnis, A.; Baumgartner, W.; Camus, A.; Steadman, J.; Sweeney, D. and Sun, F. (2010). Determination of florfenicol dose rate in feed for control of mortality in Nile tilapia infected with Streptococcus iniae. Journal of Aquatic Anim.Heal., 22:158-166

Genc, M.A., Aktas, M., Genc, E., Yilmaz, E., (2007a). Effects of dietary mannan oligosaccharide, on growth, body composition and hepatopancreas histology of Penaeus semisulcatus (de Haan 1844). Aquacult. Nutr., 13:156-161

Gibson GR, Probert HM, Loo JV, Rastall RA and Roberfroid MB (2004). Dietary modulation of the human colonic microbiota: updating the concept of prebiotics. Nutrition Res. Rev., 17: 259-275.

Gram L, Melchiorsen J, Spanggaard B, Huber I, Nielsen TF (1999). Inhibition of Vibrio anguillarum by Pseudomonas fluorescens AH2, a possible probiotic treatment of fish. Appl. Environ. Microbiol. 65: 969-973.

Grisdale-Helland B, Helland SJ, Gatlin DM (2008). The effects of dietary supplementation with mannanoligosaccharide, fructooligosaccharide or galactooligosaccharide on the growth and feed utilization of Atlantic salmon (Shalom salar). Aquacult., 283: 163-167.

Henry R and Clim C. (1964). Principles and Technics. Harper-Row. N. York, pp. 182.

Hidalgo MC, Skalli A, Abellan E, Arizcum M and Gardenete G (2006). Dietary intake of probiotics and maslinic acid in Juvenile dentex (Dentex dentex L.). Effects on growth performance, survival and liver proteolytic activies. Aqua. Nutrition., 12(4): 256-266.

Kennedy, S.B.; Tucker, J.W.; Thoresen, M. and Sennett, D. G. (1998). Current methodology for the use of probiotic bacteria in the culture of marine fish larvae. Aquaculture 98, World Aquaculture Society. Baton Rouge, pp. 286.

Kobeisy MA and Hussein SY (1995). Influence of dietary live yeast on growth performance and some blood constituents in Oreochromis niloticus Proc. $5^{\text {th }}$ Sci. Conf. Animal Nutrition, Ismailia, Egypt, 1: 417-625

Kumar R, Mukherjee SC, Prasad KP, Pal AK (2006). Evaluation of Bacillus subtilis as a probiotic to Indian major carp Labeo rohita (Ham.) Aquacult. Rese., 37:1215-1221.

Lara-Flores M, Olvera-Novoa MA, Guzman-Méndez BE and Lopez-Madrid W (2003). Use of the bacteria Streptococcus faecium and Lactobacillus acidophilus, and the yeast Saccharomyces cerevisiae as growth promoters in Nile tilapia (Oreochromis niloticus). Aquacult., 216: 193-201.

Manning TS and Gibson GR (2004). Prebiotics. Best Practice Res Clinic Gastroenterol., 18(2): 287-298.

Mazlum, Y., Güner, Ö. and Sirin S. (2011). Effects of Feeding Interval on Growth, Survival and Body Composition of Narrow-Clawed Crayfish, Astacus leptodactylus Eschscholtz, 1823 Juveniles. Turkish Journal of Fisheries and Aquatic Sciences, 11: 283-289. Doi: 10.4194 / trjfas. 2011.0213

Nayak SK, Swain P, Mukherjee SC (2007). Effect of dietary supplementation of probiotic and vitamin $\mathrm{C}$ on the immune response of Indian major carp (Labeo rohita). Fish Shellfish Immunol., 23: 892-896. 
Noh SH, Han K, Won TH, Choi YJ (1994). Effect of antibiotics, enzyme, yeast culture and probiotics on the growth performance of Israeli carp. Korean J. Anim Sci, 36: 480-486.

Olvera MA, Lara M, Guzman BE and Lopez WG (2001). Effect of the use of probiotics on growth of tilapia Oreochromis niloticus reared under stress conditions. Aquacutlure-Book of abstracts 143-J.M. Parker-Coliseum-Louisiana Stat5e Univ., Baton-Rouge-LA-70803-USA. World-Aquacult Soci., 497.

Prabhu NM, Nazar AR, Rajagopal S and Ajmal-Khan S (1999). Use of probiotics in water quality management during shrimp culture. J. Aquac. Tropics, 14 (3): $227-$ 236.

Rengpipat, S.; Phianphak, W.; Piyatiratitivoraku, S. and Menasveta, P. (1998). Effects of a probiotic bacterium on black tiger shrimp Penaeus monidon survival and growth. Aquacult., 167: 301-313.

Rengpipat, S.; Rukpratanporn, S.; Piyatirativorakul, S. and Menasaveta, P. (2000). Immunity enhancement in black tiger shrimp (Penaeus monodon) by probiont bacterium (Bacillus S11). Aquacult., 191: 271- 288.

Sahoo, PK. and Mukherjee, SC. (2001). Immuonocompressive effect of aflatoxin B1 in Indian major carp (Labeo rohita), Comp. immunol. Micro. Inf. Dis., 24: 143-149.

Sealey, W.M.; Barrows, F.T.; Hang, A.; Johansen, K.A.; Overturf, K.; LaPatra, S.E. and Hardy, R.W. (2007). Evaluation of the ability of barley genotypes containing different amounts of $\beta$-glucan to alter growth and disease resistance of rainbow trout Oncorhynchus mykiss. Animal Feed

Science and Technology 141 (1-2): 115-128. DOI: 10. 1016/j. anifeedsci.05.022.

Siddiqui, AQ.; Howlader, MS. and Adam, AA. (1988). Effects of dietary protein levels on growth, feed conversion and protein utilization in fry and young Nile Tilapia (Oreochromis niloticus). Aquacult., 70: 63 -73.

Shelby, RA.; Lim, C.; Yildirim, M. and Klesius, PH. (2006). Effects of probiotic bacteria as dietary supplements on growth and disease resistance in young channel catfish. Intalurus punctatus (Rafinesque). Journal of Applied Aquacult., 18(2): 49-60.

Staykov, Y.; Spring, P.; Denev, SA. and Sweetman, J. (2007). Effect of a mannan oligosaccharide on the growth performance and immune status of rainbow trout (Oncorhynchus mykiss). Aquacul. Int., 2: 153-161.

Tewary, A. and Patra, BC. (2011). Oral administration of baker's yeast (Saccharomyces cerevisiae) acts as a growth promoter and immunomodulator in Labeo rohita (Ham.), J. Aquac. Res. Development, [online], 2 (1)

Tovar-Ramírez, D.; Zambonino-Infante, J.; Cahu, C.; Gatesoupe, FJ. and VázqueJuárwz, R. (2004). Influence of dietary live yeast on European sea bass (Dicentrarchus labrax) larval development. Aquacult., 234: 415-427.

Wang YB, Xu ZR and Xia MS (2005): The effectiveness of commercial probiotics in Northern White Shrimp (Penaeus vannamei L.) ponds. Fish. Sci., 71(5): 1036-1041.

Wang Y and Xu Z (2006). Effect of probiotics for common carp (Cyprinus carpio) based on growth performance and digestive enzyme activities. Animal Feed Science and Technol., 127: 283-292.

Wang, Y.B. (2007). Effect of probiotics on growth performance and digestive enzyme activity of the shrimp Penaeus vannamei. Aquacult., 269: 259-264. Doi: 10.1016/j.Aquacult.2007.05.035 
Wang, Y., GU, Q. (2010). Effect of probiotics on white shrimp (Penaeus vannamei) growth performance and immune response. Mar. Biol. Rese. 6: 327-332.

Wotton ID and Freeman H (1982). Microanalysis in Medical Biochemistry. Churchill, New York, USA.

Yanbo W, Zirong X. (2006). Effect of probiotics for common carp (Cyprinus carpio) based on growth performance and digestive enzyme activities. Animal Feed Sci Technol, 127: 283-292.

Yilmaz E, Genc MA, Genc E (2007). Effects of dietary mannan oligosaccharides on growth, body composition, and intestine and liver histology of rainbow trout, Oncorhynchus mykiss. The Israeli J. Aquacult., 59:182-188.

Yousefian, M., \& Amiri, M. S. (2009). A. review of the use of prebiotic in aquaculture for fish and shrimp. Afr. J.Biotechnol, 8: 7313-7318.

\section{ARABIC SUMMRY}

$$
\begin{aligned}
& \text { ARABIC SUMMRY } \\
& \text { تقييم تاثير المكملات الغذائية من البريبيوتك والبروبيوتيك على اداء النمو وبعض مكونات الدم لزريعة } \\
& \text { المبروك العادى }
\end{aligned}
$$

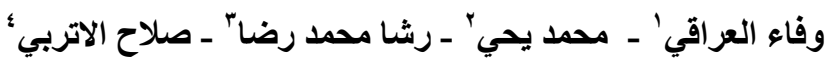

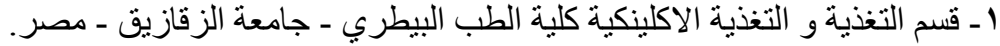

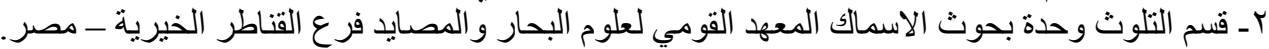

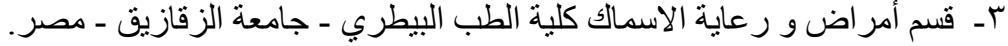

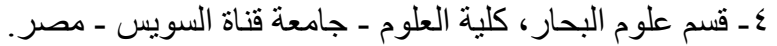

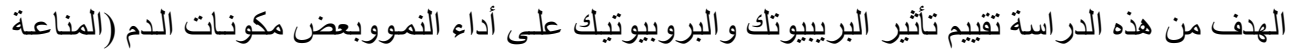

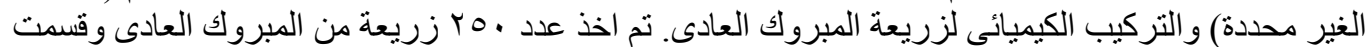

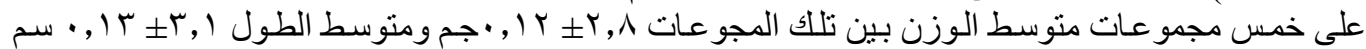

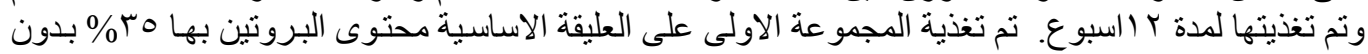

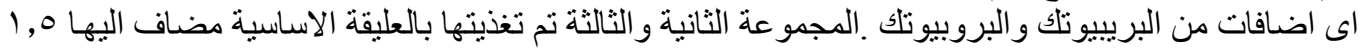

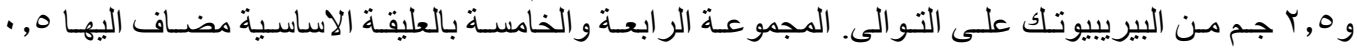

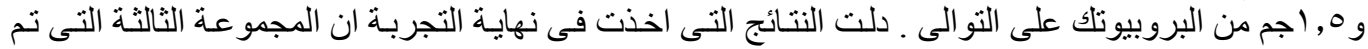

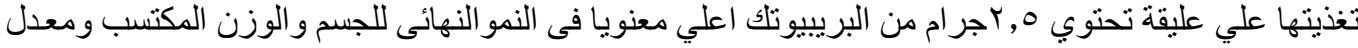

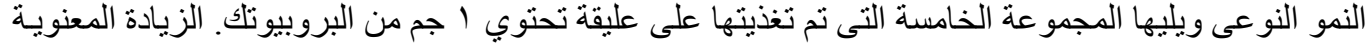

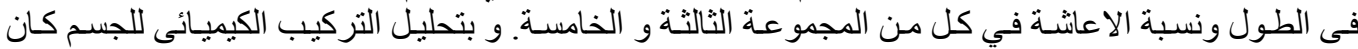

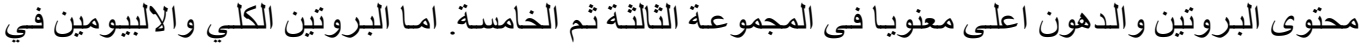

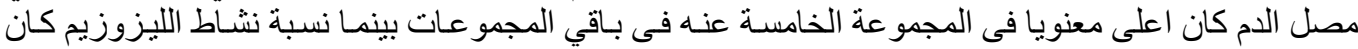

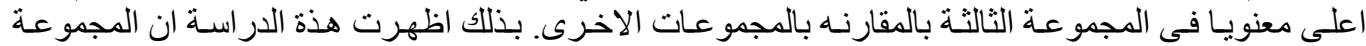

$$
\begin{aligned}
& \text { الثالثة المضاف اليها ه, ج جم من البريبيوتلك كانت افضل من المجمو عات الاخرى لزريعة المبروك العادى. }
\end{aligned}
$$

